\title{
KONSENTRASI KLOROFIL DAUN SEBAGAI INDIKATOR KEKURANGAN AIR PADA TANAMAN
}

\author{
Nio Song $\mathrm{Ai}^{1)}$ dan Yunia Banyo ${ }^{1)}$ \\ ${ }^{1)}$ Program Studi Biologi FMIPA Universitas SamRatulangi Manado, 95115 \\ email: nio_ai@yahoo.com
}

\begin{abstract}
ABSTRAK
Kekurangan air mempengaruhi semua aspek pertumbuhan tanaman, yang meliputi proses fisiologi, biokimia, anatomi dan morfologi. Salah satu respons fisiologis tanaman terhadap kekurangan air adalah penurunan konsentrasi klorofil daun yang dapat disebabkan oleh pembentukan klorofil dihambat, penurunan enzim rubisco, dan terhambatnya penyerapan unsur hara, terutama nitrogen dan magnesium yang berperan penting dalam sintesis klorofil. Kandungan klorofil daun dapat dipakai sebagai indikator yang terpercaya untuk mengevaluasi ketidakseimbangan metabolisme antara fotosintesis dan hasil produksi pada saat kekurangan air.
\end{abstract}

Kata kunci: cekaman, fotosintesis, respons fisiologi

\section{THE CONCENTRATION OF LEAF CHLOROPHYLL AS WATER-DEFICIT INDICATOR IN PLANTS}

\begin{abstract}
Water deficit influences all aspects of plant growth including physiological, biochemical, anatomical and morphological processes. One of plant physiological responses to water deficit is the decrease of leaf-chlorophyll concentration because the chlorophyll synthesis is inhibited, the rubisco enzyme was reduced and the absorption of nutrients, especially nitrogen and magnesium that are required for chlorophyll synthesis, was inhibited. The concentration of leaf chlorophyll is able to be used as reliable indicator for evaluating unbalanced metabolism between photosynthesis and plant production under water deficit.
\end{abstract}

Keywords: stress, photosynthesis, physiological response

\section{PENDAHULUAN}

Cekaman abiotik seperti kekeringan, kadar garam tinggi (salinitas), suhu tinggi atau rendah, keasaman tanah, tercatat menurunkan hasil pertanian dunia hingga lebih dari 50\% (Wood, 2005). Berbagai cekaman tersebut mengakibatkan perubahanperubahan pada morfologi, fisiologi, dan biokimia,yang akhirnya akan berpengaruh buruk pada pertumbuhan tanaman serta produktivitasnya. Kekeringan, salinitas, temperatur ekstrim, dan cekaman oksidatif, seringkali saling berhubungan dan menginduksi kerusakan yang sama pada sel (Levitt, 1980).

Cekaman kekeringan merupakan istilah untuk menyatakan bahwa tanaman mengalami kekurangan air akibat keterbatasan air dari lingkungannya yaitu media tanam. Cekaman kekeringan pada tanaman dapat disebabkan oleh kekurangan suplai air di daerah perakaran dan permintaan air yang berlebihan oleh daun akibat laju evapotranspirasi yang melebihi lajuabsorpsi air walaupun keadaan air tanah tersedia dengan cukup (Levitt,1980; Bray, 1997).

Kekurangan air mempengaruhi semua aspek pertumbuhan tanaman, yang meliputi proses fisiologi, biokimia, anatomi dan morfologi. Pada saat kekurangan air, sebagian stomata daun menutup sehingga terjadi hambatan masuknya $\mathrm{CO}_{2}$ dan menurunkan aktivitas fotosintesis. Selain menghambat aktivitas fotosintesis, kekurangan air juga menghambat sintesis protein dan dinding sel (Salisbury dan Ross, 1992). Tanaman yang mengalami kekurangan air secara umum mempunyai ukuran yang lebih kecil dibandingkan dengan tanaman yang tumbuh normal (Kurniasari et al., 2010). Kekurangan air menyebabkan 
penurunan hasil yang sangat signifikan dan bahkan menjadi penyebab kematian pada tanaman (Salisbury dan Ross, 1992).

Respons tanaman yang mengalami kekurangan air dapat merupakan perubahan di tingkat selular dan molekular yang ditunjukkan dengan penurunan laju pertumbuhan, berkurangnya luas daun dan peningkatan rasio akar : tajuk. Tingkat kerugian tanaman akibat kekurangan air dipengaruhi oleh beberapa faktor, antara lain intensitas kekeringan yang dialami, lamanya kekeringan dan tahap pertumbuhan saat tanaman mengalami kekeringan.Dua macam respons tanaman yang dapat memperbaiki status jika mengalami kekeringan adalah mengubah distribusi asimilat baru dan mengatur derajat pembukaan stomata. Pengubahan distribusi asimilat baruakan mendukung pertumbuhan akar daripada tajuk, sehingga dapat meningkatkan kapasitas akar menyerap air serta menghambat pertumbuhan tajuk untuk mengurangi transpirasi. Pengaturan derajat pembukaan stomata akan menghambat hilangnya air melalui transpirasi (Mansfield dan Atkinson,1990).

Pengukuran karakter fisiologi seperti kandungan klorofil, merupakan salah satu pendekatan untuk mempelajari pengaruh kekurangan air terhadap pertumbuhan dan hasil produksi, karena parameter ini berkaitan erat dengan laju fotosintesis (Li et al., 2006). Kekurangan air dari tingkat paling ringan sampai paling berat mempengaruhi prosesproses biokimia yang berlangsung dalam sel. Kekurangan air mempengaruhi reaksi-reaksi biokimia fotosintesis, sehingga laju fotosintesis menurun (Fitter dan Hay, 1994; Ju dan Zhang, 1999). Salah satu aspek fotosintesis yang sangat sensitif terhadap kekurangan air adalah biosintesis klorofil dan pembentukan protoklorofil terhambat pada potensial air sedikit dibawah 0 atm (Salisbury dan Ross, 1992).

Evaluasi toleransi tanaman terhadap kekurangan air dapat dilakukan dengan mengidentifikasi ciri-ciri morfologi, anatomi, dan fisiologi yang berkaitan erat dengan hasil produksi tanaman di lingkungan yang kekurangan air. Pembahasan dalam makalah ini dibatasi pada ciri-ciri fisiologi khususnya konsentrasi klorofil daun sebagai respons tanaman terhadap kekurangan air dan bertujuan untuk memberikan informasi tentang konsentrasi klorofil daun yang potensial sebagai indikator kekurangan air pada tanaman. Informasi ini dapat diterapkan dalam seleksi tanaman yang toleran terhadap kekurangan air dalam program pemuliaan tanaman.

\section{KLOROFIL: Pigmen Utama Pada Tanaman}

Istilah klorofil berasal dari bahasa Yunani yaitu chloros artinya hijau dan phyllos artinya daun. Istilah ini diperkenalkan pada tahun 1818, dan pigmen tersebut diekstrak dari tanaman dengan menggunakan pelarut organik. Klorofil adalah pigmen pemberi warna hijau pada tumbuhan, alga dan bakteri fotosintetik. Pigmen ini berperan dalam proses fotosintesis tumbuhan dengan menyerap dan mengubah energi cahaya menjadi energi kimia.Klorofil mempunyai rantai fitil $\left(\mathrm{C}_{20} \mathrm{H}_{39} \mathrm{O}\right)$ yang akan berubah menjadi fitol $\left(\mathrm{C}_{20} \mathrm{H}_{39} \mathrm{OH}\right)$ jika terkena air dengan katalisator klorofilase. Fitol adalah alkohol primer jenuh yang mempunyai daya afinitas yang kuat terhadap $\mathrm{O}_{2}$ dalam proses reduksi klorofil (Muthalib, 2009).

Sifat fisik klorofil adalah menerima dan atau memantulkan cahaya dengan gelombang yang berlainan (berpendar = berfluoresensi). Klorofil banyak menyerap sinar dengan panjang gelombang antara 400$700 \mathrm{~nm}$, terutama sinar merah dan biru. Sifat kimia klorofil, antara lain (1) tidak larut dalam air, melainkan larut dalam pelarut organik yang lebih polar, seperti etanol dan kloroform; (2) inti $\mathrm{Mg}$ akan tergeser oleh 2 atom $\mathrm{H}$ bila dalam suasana asam, sehingga membentuk suatu persenyawaan yang disebut feofitin yang berwarna coklat (Dwidjoseputro, 1994).

Klorofil merupakan faktor utama yang mempengaruhi fotosintesis. Fotosintesis merupakan proses perubahan senyawa anorganik $\left(\mathrm{CO}_{2}\right.$ dan $\left.\mathrm{H}_{2} \mathrm{O}\right)$ menjadi senyawa organik (karbohidrat) dan $\mathrm{O}_{2}$ dengan bantuan cahaya matahari. Klorofil merupakan pigmen utama yang terdapat dalam kloroplas. Kloroplas (Gambar1) adalah organel sel tanaman yang mempunyai membran luar, membran dalam, ruang antar membran dan stroma. Permukaan membran internal yang disebut tilakoid akan membentuk kantong pipih dan pada posisi tertentu akan bertumpukan dengan rapi membentuk struktur yang disebut granum. Seluruh 
granum yang terdapat pada kloroplas disebut grana. Tilakoid yang memanjang dan menghubungkan granum satu dengan yang lain di dalam stroma disebut lamela. Stroma merupakan rongga atau ruang dalam kloroplas dan berisi air beserta garam-garam yang terlarut dalam air. Klorofil terdapat di dalam ruang tilakoid ( Thorpe, 1984; Campbell et al., 2003).

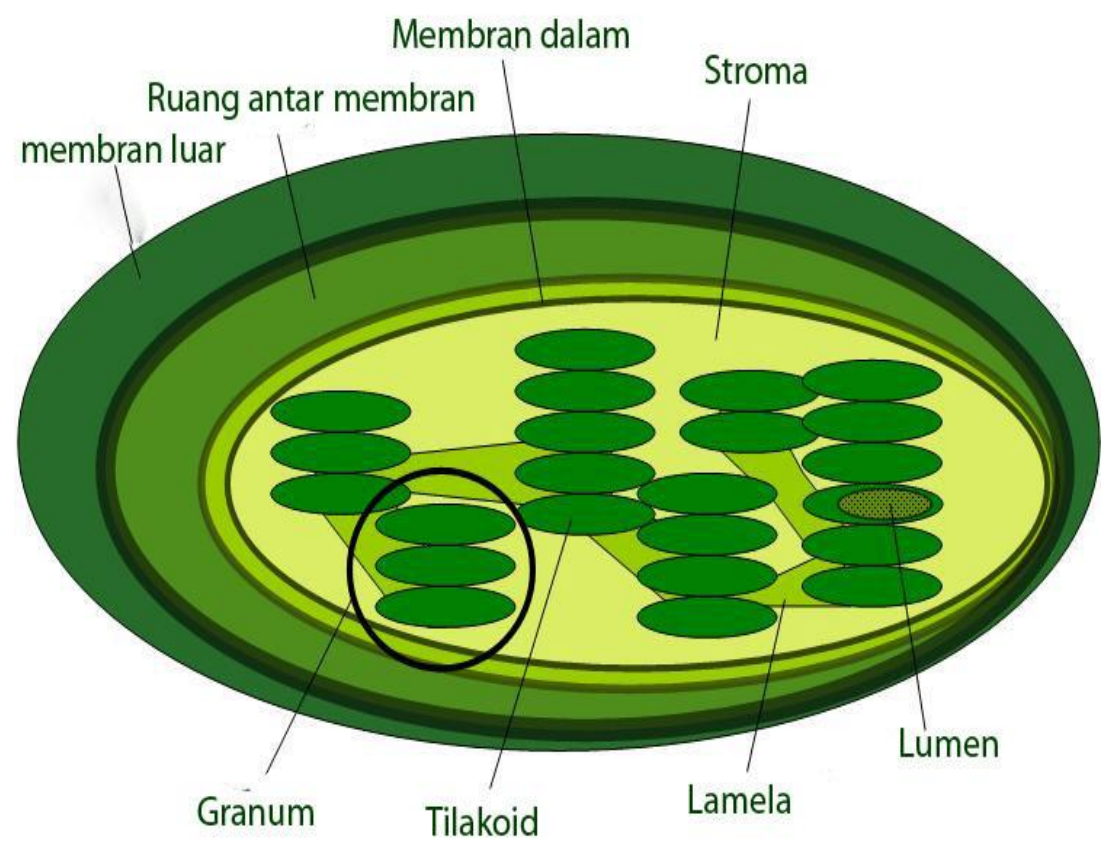

Gambar 1. Struktur kloroplas beserta bagian-bagiannya (Anonim, 2011)

Tiga fungsi utama klorofil dalam proses fotosintesis adalah memanfaatkan energi matahari, memicu fiksasi $\mathrm{CO}_{2}$ untuk menghasilkan karbohidrat dan menyediakan energi bagi ekosistem secara keseluruhan. Karbohidrat yang dihasilkan dalam fotosintesis diubah menjadi protein, lemak, asam nukleat dan molekul organik lainnya. Klorofil menyerap cahaya yang berupa radiasi elektromagnetik pada spektrum kasat mata (visible). Cahaya matahari mengandung semua warna spektrum kasat mata dari merah sampai violet, tetapi tidak semua panjang gelombang diserap dengan baik oleh klorofil. Klorofil dapat menampung cahaya yang diserap oleh pigmen lainnya melalui fotosintesis, sehingga klorofil disebut sebagai pigmen pusat reaksi fotosintesis (Bahri, 2010).

Tanaman tingkat tinggi mempunyai dua macam klorofil yaitu klorofil a $\left(\mathrm{C}_{55} \mathrm{H}_{72} \mathrm{O}_{5} \mathrm{~N}_{4} \mathrm{Mg}\right)$ yang berwarna hijau tua dan klorofil b $\left(\mathrm{C}_{55} \mathrm{H}_{70} \mathrm{O}_{6} \mathrm{~N}_{4} \mathrm{Mg}\right)$ yang berwarna hijau muda. Klorofil a dan klorofil b paling kuat menyerap cahaya di bagian merah (600$700 \mathrm{~nm}$ ), dan paling sedikit menyerap cahaya hijau (500-600 nm). Perbandingan kedua macam klrofil ini dapat dilihat pada Tabel 1 dan Gambar 2. Sedangkan cahaya berwarna biru diserap oleh karotenoid. Karotenoid membantu menyerap cahaya, sehingga spektrum cahaya matahari dapat dimanfaatkan dengan lebih baik. Energi yang diserap oleh klorofil b dan karotenoid diteruskan kepada klorofil a untuk digunakan dalam proses fotosintesis fase I (reaksi terang) yang terdiri dari fotosistem I dan II, demikian pula dengan klorofil-b. Klorofil a paling banyak terdapat pada Fotosistem II sendangkan Klorofil b paling banyak terdapat pada Fotosistem I (Anonim 2011).

Table 1. Perbandingan pigmen klorofil a dan klorofil $\mathrm{b}$ (Anonim, 2011)

\begin{tabular}{|c|c|c|}
\hline Aspek & Klorofil a & Klorofil b \\
\hline Rumus kimia & $\mathrm{C}_{55} \mathrm{H}_{72} \mathrm{O}_{5}$ & $\mathrm{C}_{55} \mathrm{H}_{70} \mathrm{O}_{6} \mathrm{~N}_{4} \mathrm{Mg}$ \\
$\mathrm{N}_{4} \mathrm{Mg}$ & $\mathrm{CH}_{3}$ & $\mathrm{CH}$ \\
\hline Gugus pengikat & $\begin{array}{c}\text { cahaya biru- } \\
\text { diserap } \\
\text { melet dan } \\
\text { merah }\end{array}$ & $\begin{array}{c}\text { cahaya biru dan } \\
\text { oranye }\end{array}$ \\
\hline Absorbsi & $\begin{array}{c}\text { pada } \lambda 673 \\
\text { maksimum }\end{array}$ & pada $\lambda 455-640 \mathrm{~nm}$ \\
\hline
\end{tabular}




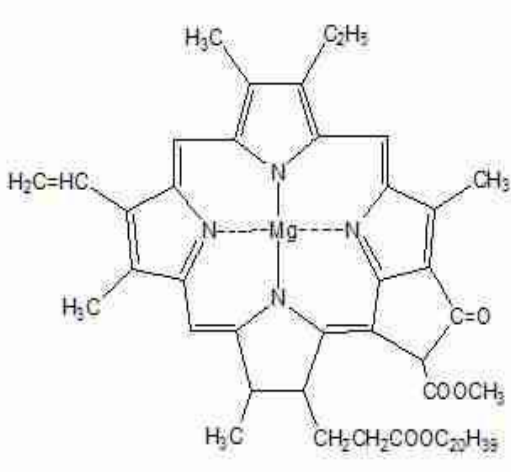

klorofil a

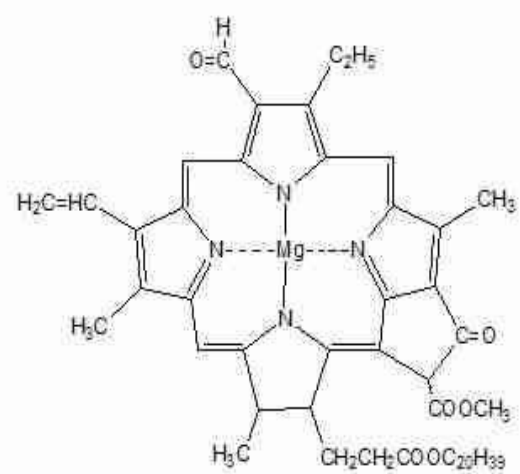

klorofil b

Gambar 2. Struktur klorofil a dan b (Anonim, 2011)

\section{Kekurangan Air Sebagai Cekaman Abiotik Pada Tanaman}

Setiap tanaman memerlukan kondisi lingkungan yang sesuai untuk pertumbuhan dan perkembangannya. Kondisi lingkungan tempat tanaman berada selalu mengalami perubahan. Perubahan yang terjadi mungkin saja masih berada dalam batas toleransi tanaman tersebut, tetapi seringkali tanaman mengalami perubahan lingkungan yang dapat menyebabkan menurunnya produktivitas dan bahkan kematian tanaman. Hal ini menunjukkan bahwa setiap tanaman memiliki faktor pembatas dan daya toleransi terhadap lingkungan (Purwadi, 2011).

Cekaman (stress) lingkungan adalah kondisi lingkungan yang memberikan tekanan pada tanaman dan mengakibatkan respons tanaman terhadap faktor lingkungan tertentu lebih rendah daripada respons optimumnya pada kondisi normal. Kondisi lingkungan yang memungkinkan tanaman untuk memberikan respons maksimum terhadap suatu faktor lingkungan bukan merupakan cekaman bagi tanaman. Cekaman lingkungan dapat berupa faktor eksternal dan faktor internal. Faktor eksternal meliputi kondisi lingkungan yang tidak mendukung pertumbuhan dan perkembangan bagian tanaman seperti kekurangan dan kelebihan unsur hara, kekurangan dan kelebihan air, suhu yang terlalu rendah atau terlalu tinggi. Sedangkan faktor internal adalah gen individu tersebut (Purwadi, 2011).
Cekaman lingkungan dapat berupa faktor abiotik dan faktor biotik. Faktor abiotik dapat berupa cahaya, air, suhu, dan zat hara dalam tanah, sedangkan yang termasuk faktor biotik ialah herbivora, parasit atau patogen, dan predator (Mahmuddin, 2009).

Ketersediaan air merupakan salah satu cekaman abiotik yang dapat menghambat pertumbuhan dan perkembangan suatu tanaman. Tanaman tidak akan dapat hidup tanpa air, karena air merupakan faktor utama yang berperan dalam proses fisiologi tanaman. Air merupakan bagian dari protoplasma dan menyusun $85-90 \%$ dari berat keseluruhan jaringan tanaman. Air juga merupakan reagen yang penting dalam fotosintesis dan dalam reaksi-reaksi hidrolisis. Di samping itu air juga merupakan pelarut garam-garam, gas-gas dan zat-zat lain yang diangkut antar sel dalam jaringan untuk memelihara pertumbuhan sel dan mempertahankan stabilitas bentuk daun. Air juga berperan dalam proses membuka dan menutupnya stomata (Cheeta, 2011).

Jumlah air yang dibutuhkan dalam pertumbuhan tanaman bervariasi, tergantung pada jenis tanaman. Dalam kehidupan tanaman air berperan 1) sebagai pelarut unsur-unsur hara yang terkandung dalam tanah, sehingga dapat diambil oleh tanaman dengan mudah melalui akar dan diangkut ke bagian tanaman yang membutuhkan (termasuk daun yang berfotosintesis) melalui 
xilem;2) sebagai pelarut hasil fotosintesis untuk didistribusikan keseluruh bagian tanaman melalui floem dan fotosintat tersebut akan digunakan oleh tanaman untuk proses pertumbuhan (Hendriyani dan Setiari, 2009).

Kekurangan air atau kekeringan pada tanamandapat dibagi ke dalam tiga kelompok yaitu:

a) Cekaman ringan: jika potensial air daun menurun 0,1 $\mathrm{MPa}$ atau kandungan air nisbi menurun $8-10 \%$

b) Cekaman sedang: jika potensial air daun menurun $1,2 \mathrm{~s} / \mathrm{d}$ 1,5 $\mathrm{MPa}$ atau kandungan air nisbi menurun $10-20 \%$

c) Cekaman berat: jika potensial air daun menurun $>1,5 \mathrm{MPa}$ atau kandungan air nisbi menurun $>20 \%$

Tanaman dikatakan mengalami kekeringan jika kehilangan lebih dari 50\% air dari jaringannya (Cheeta, 2011).

Kekurangan air mengakibatkan perubahan di tingkat molekuler, seluler, fisiologi dan morfologi. Perubahan yang terjadi dapat berupa pengurangan volume sel, penurunan luas daun, penebalan daun, adanya rambut pada daun, perubahan ekspresi gen, perubahan metabolisme karbon dan nitrogen, perubahan produksi dan aktivitas enzim dan hormon, peningkatan sensitivitas stomata, penurunan laju fotosintesis. Kekurangan air yang terus-menerus akan menyebabkan perubahan tidak dapat balik dan pada akhirnya tanaman akan mati (Winarno, 1991).

Ada beberapa cara yang dapat dilakukan oleh tanaman untuk merespons kekurangan air, antara lain:

1. menutup stomata dan memperlambat perluasan permukaan daun untuk mengurangi laju transpirasi (Campbell et al., 2003 ).

2. menurunkan pemanjangan akar, kedalaman penetrasi dan diameter akar bagi tanaman yang tidak toleran terhadap kekurangan air, sedangkan yang toleran mempunyai perakaran yang lebih banyak, volume akar yang lebih besar, dan rasio akar dan tajuk yang besar (Haryati, 2008).

3. akumulasi senyawa biokimia yang berperan dalam penyesuaian osmotik seperti prolin, asam absisat, protein dehidrin, total gula, pati, sorbitol, vitamin $\mathrm{C}$, asam organik, aspargin, glisin-betain, serta superoksida dismutase dan $\mathrm{K}^{+}$yang bertujuan untuk menurunkan potensial osmotik sel tanpa membatasi fungsi enzim (Sinaga, 2008; Nio et al., 2011 ).

\section{Kandungan Klorofil Sebagai Indikator Tanaman yang Mengalami Kekurangan Air}

Fotosintesis merupakan proses penting untuk mempertahankan pertumbuhan dan perkembangan tanaman produksi ( $\mathrm{Li}$ et al., 2006). Fotosintesis pada tanaman berpembuluh angkut sensitif terhadap cekaman biotik (patogen) maupun abiotik (kekeringan, temperatur, defisiensi nutrient, polutan), dan terutama sangat sensitif terhadap cekaman kekeringan (van der Mescht et al., 1999; Li et al., 2006). Kurangnya ketersediaan air akan menghambat sintesis klorofil pada daun akibat laju fotosintesis yang menurun dan terjadinya peningkatan temperatur dan transpirasi yang menyebabkan disentegrasi klorofil (Hendriyani dan Setiari, 2009).

Klorofil merupakan komponen kloroplas yang utama dan kandungan klorofil relatif berkorelasi positif dengan laju fotosintesis ( $\mathrm{Li}$ et al., 2006). Klorofil disintesis di daun dan berperan untuk menangkap cahaya matahari yang jumlahnya berbeda untuk tiap spesies. Sintesis klorofil dipengaruhi oleh berbagai faktor seperti cahaya, gula atau karbohidrat, air, temperatur, faktor genetik, unsur-unsur hara seperti $\mathrm{N}$, $\mathrm{Mg}, \mathrm{Fe}, \mathrm{Mn}, \mathrm{Cu}, \mathrm{Zn}, \mathrm{S}$ dan $\mathrm{O}$ (Hendriyani dan Setiari, 2009).

Kompleks proteinklorofil merupakan komponen fotosintesis yang penting (van der Mescht et al., 1999). Radiasi cahaya yang diterima oleh tanaman dalam fotosintesis diabsorbsi oleh klorofil dan pigmen tambahan yang merupakan kompleks proteinklorofil. Selanjutnya energi radiasi akan ditransfer ke pusat reaksi fotosistem I dan II yang merupakan tempat terjadinya perubahan energi cahaya menjadi energi kimia (Li et al., 2006). Dua mekanisme yang terlibat dalam pembentukan kompleks proteinklorofil adalah distribusi klorofil yang baru disintesis dan redistribusi klorofil yang sudah ada. Klorofil b adalah hasil biosintesis dari klorofil a dan berperan penting dalam reorganisasi fotosistem selama adaptasi terhadap kualitas dan intensitas cahaya. Oleh sebab itu hilangnya klorofil a dan b berpengaruh negatif terhadap efisiensi fotosintesis (van der Mescht et al., 1999). 
Keadaan tanaman yang tetap hijau berkaitan dengan peningkatan produksi dan efisiensi transpirasi pada saat tanaman mengalami kekeringan, seperti pada sorgum (Sorgum bicolor), jagung (Zea mays L.) dan gandum (Triticum aestivum L.) (Li et al., 2006). Secara umun kandungan klorofil a, klorofil b, dan klorofil total pada daun kentang (Solanum tuberosum L.) setelah kekeringan selama 4 minggu lebih rendah dibandingkan dengan yang disirami. Tetapi kandungan klorofil a, kandungan klorofil $b$ dan klorofil total pada kentang bervariasi dan tidak menggambarkan sensitivitas atau toleransi terhadap kekeringan dengan jelas (van der Mescht et al., 1999). Pada saat kekeringan konsentrasi klorofil pada genotype barley (Hordeum vulgare L.) yang toleran dan sensitif menurun dan penurunan pada genotipe yang sensitif lebih besar daripada genotipe yang toleran. Konsentrasi klorofil pada genotipe barley yang toleran kekeringan lebih tinggi daripada genotipe yang sensitif terhadap kekeringan. Kandungan klorofil daun dapat dipakai sebagai indikator toleransi terhadap kekeringan dalam seleksi plasma nutfah barley (Li et al, 2006). Kekurangan air pada kelapa kerdil hijau Brazilia (Cocos nucifera L. nana) mengakibatkan penurunan konsentrasi klorofil daun tiap unit luas daun (Gomes et al., 2008). Penurunan kandungan air media tanaman jarak pagar (Jatropha curcas L.) dari $40 \%$ menjadi $32 \%$ menurunkan kandungan klorofil hingga 0,004 $\mathrm{mg} / \mathrm{g}$ daun (Syafi 2008). Konsentrasi klorofil a klorofil b dan klorofil total tidak berbeda nyata pada kacang panjang (Vigna sinensis L.) dengan variasi penyiraman $1 / 2$ kapasitas lapang, dan 11/2 kapasitas lapang (Hendriyani dan Setiari, 2009). Konsentrasi klorofil total dan klorofil a pada daun padi (Oryza sativa L.) potensial dipakai sebagai indikator cekaman kekeringan yang diinduksi dengan polietilen glikol (Nio, 2010). Perlakuan kekeringan selama 7 hari menurunkan kandungan klorofil total daun jahe (Zingiber officinale L.) (Nio, 2011). Penurunan kandungan klorofil merupakan salah satu respons fisiologis tanaman yang kekurangan air.

Penurunan kandungan klorofil pada saat tanaman kekurangan air berkaitan dengan akitivitas perangkat fotosintesis dan menurunkan laju fotosintesis tanaman.
Pembentukan klorofil dihambat (Salisbury dan Ross 1992) dan penurunan enzim rubisco (Pangaribuan 2001) terjadi pada saat tanaman kekurangan. Kekurangan air akan mempengaruuhi kandungan dan organisasi klorofil dalam kloroplas pada jaringan (Harjadi dan Yahya 1988 dalam Syafi 2008). Di samping itu penyerapan unsur hara dari tanah oleh akar terhambat, sehingga mempengaruhi ketersediaan unsur $\mathrm{N}$ dan $\mathrm{Mg}$ yang berperan penting dalam sintesis klorofil (Syafi 2008). Kandungan klorofil dapat dipakai sebagai indikator yang terpercaya untuk mengevaluasi ketidakseimbangan metabolisme antara fotosintesis dan hasil produksi pada saat kekurangan air ( $\mathrm{Li}$ et al., 2006)

\section{KESIMPULAN}

Respons tanaman terhadap kekurangan air pada umumnya ditunjukkan dengan penurunan konsentrasi klorofil daun. Respons fisiologis, seperti konsentrasi klorofil daun, dapat dipakai sebagai salah satu indikator toleransi tanaman terhadap kekurangan air untuk diterapkan dalam seleksi varietas tanaman produksi yang toleran terhadap kekurangan air.

\section{DAFTAR PUSTAKA}

Anonim. 2011. Klorofil. Situs Web Wikipedia Indonesia, Diakses pada tanggal 9 Oktober 2011.

Bahri, S. 2010. Klorofil. Diktat Kuliah Kapita Selekta Kimia Organik. Universitas Lampung.

Bray, E.A. 1997. Plant responses to water deficit. Trend in Plant Sci. 2:48-54.

Campbell, N.A, J.B. Reece, L.G. Mitchell. 2003. Biologi Jilid 1 (Terjemahan) Erlangga. Jakarta.

Cheeta. 2011. Air sebagai Sumber Kehidupan. http://cheeta-cheetahz. blogspot.com/2011/03/.html. Diakses pada tanggal 1 November 2011.

Dwidjoseputro, D. 1994. Pigmen Klorofil. Erlangga. Jakarta. 
Fitter, A.H. dan R.K.M. Hay. 1994. Fisiologi Lingkungan Tanaman. Gadjah Mada University Press. Yogyakarta.

Gomes, F.B., M.A. Olivia, M.S. Nielke, A.F. de Almeida, H.G. Leite, L.A. Aquine. 2008. Photosynthetic Limitations in Leaves of Young Brazilian Green Dwarf Coconut (Cocos nucifera $\mathbf{L}$. 'nana') Palm under Well-Watered Conditions and Recovering from Drought Stress. Environmental and Experimental Botany 62: 195-204.

Haryati. 2008. Pengaruh Cekaman Air terhadap Pertumbuhan dan Hasil Tanaman.

http://library.usu.ac.id/download/fp/hsl pertanian-haryati2.pdf. Diakses pada tanggal 17 Oktober 2011.

Hendriyani, I. S dan N. Setiari. 2009. Kandungan Klorofil dan Pertumbuhan Kacang Panjang (Vigna sinensis) pada Tingkat Penyediaan Air yang Berbeda. J. Sains \& Mat. 17(3): 145-150.

Ju, C. dan J. Zhang. 1999. Effect of Water Stress on Photosystem II Photochemistry and Its Thermostability in Wheat Plants. Journal of Experimental Botany 50 (336): 1196-1206.

Levitt, J. 1980. Responses of Plants to Environmental Stresses. II Water, radiation, salt and other stresses. 2nd Ed. Academic Press. New York.

Li, R., P. Guo, M. Baum, S. Grando, S. Ceccarelli. 2006. Evaluation of Chlorophyll Content and Fluorescence Parameters as Indicators of Drought Tolerance in Barley. Agricultural Sciences in China 5 (10): 751-757.

Kurniasari, A. M. Adisyahputra, R. Rosman. 2010. Pengaruh Kekeringan pada Tanah Bergaram $\mathrm{NaCl}$ terhadap Pertumbuhan Tanaman Nilam. Jurusan Biologi FMIPA UI. Jakarta.

Mansfield, T.A. dan C.J. Atkinson. 1990. Stomatal Behavior in Water Stressed Plants. Dalam: Alscher dan Cumming (Eds). Stress Response in Plant adaptation and Acclimation Mechanisms. Wiley Liss Inc., New York.

Mahmuddin. 2009. Cekaman pada Makhluk Hidup. http://mahmuddin.wordpress.com/2009 /10/16. Diakses tanggal 1 November 2011.

Muthalib, A. 2009. Klorofil dan Penyebaran di Perairan. http://wwwabdulmuthalib. co.cc/2009/06/. Diakses pada tanggal 11 Oktober 2011.

Nio, S. A. 2011. Biomasa dan Kandungan Klorofil Total Daun Jahe (Zingiber officinale L.) yang Mengalami Cekaman Kekeringan. Jurnal Ilmiah SAINS 11: 190-195.

Nio, S. A., G. R. Cawthray, L. J. Wade, T. D. Colmer. 2011. Pattern of Solutes Accumulated during Leaf Osmotic Adjustment as Related to Duration of Water for Wheat at the Reproductive Stage. Plant Physiology and Biochemistry 49 (10): 1126-1137.

Nio, S. A. 2010. Pengujian Kandungan Klorofil Total, Klorofil A dan B sebagai Indikator Cekaman Kekeringan pada Padi (Oryza sativa L.). Jurnal Ilmiah SAINS 10: 86-90.

Pangaribuan, Y. 2001. Studi Karakter Morfofisiologi Tanaman Kelapa Sawit (Elais guineensis Jacq.) di Pembibitan terhadaap Cekaman Kekeringan. Tesis. IPB. Bogor.

Purwadi, E. 2011. Pengujian Ketahanan Benih terhadap Cekaman Lingkungan. http://www.masbied.com/2011/05/23/. Diakses pada tanggal 1 November 2011.

Salisbury, F.B. and C.W. Ross. 1992. Plant Physiology. 4rd Ed. Wadsworth Publishing Company. California.

Sinaga, R. 2008. Analisis Model Ketahanan Rumput Gajah dan Rumput Raja akibat Cekaman Kekeringan berdasarkan Respons Anatomi Akar dan Daun. Jurnal Biologi Sumatra, 2 (1): 17-20.

Syafi, S. 2008. Respons Morfologis dan Fisiologis Bibit Berbagai Genotipe Jarak Pagar (Jatropha curcas L.) terhadap Cekaman Kekeringan. Tesis. IPB. Bogor.

Thorpe, N. O. 1984. Cell Biology. John Wiley and Sons. New York.

van der Mescht, A., J. A. de Ronde, F.T. Rossouw. $1999 . \quad$ Chlorophyll Fluorescence and Chlorophyll Content as A Measure of Drought Tolerance in Potato. South African Journal of Science 95:407-412. 
Winarno, F.G. 1991. Kimia Pangan dan Gizi.

Gramedia Pustaka Utama. Jakarta.

Wood, A.J. 2005. Eco-physiological adaptations to limited water environments. Dalam: Jenks MA, Hasegawa PM (ed) Plant Abiotic Stress. Blackwell Publishing Ltd, India. h 1-13. 